\title{
ENHANCEMENT OF URBAN ECOSYSTEM SERVICES BY URBAN AGRICULTURE: A SOUTHEAST ASIAN PERSPECTIVE
}

Azlan Abas, ${ }^{1}$ Jasmin Arif Shah, ${ }^{2}$ Nur Shazwanie Rosehan, ${ }^{1}$ Noordeyana Tambi, ${ }^{1}$ \& Sytty Mazian Mazlan ${ }^{3}$

${ }^{1}$ Centre for Research in Development, Social and Environment (SEEDS), Faculty of Social Sciences and Humanities, Universiti Kebangsaan Malaysia (UKM)

${ }^{2}$ Department of Agriculture Technology, Faculty of Agriculture, Universiti Putra Malaysia (UPM)

${ }^{3}$ Research and Development Department, National Institute of Occupational Safety and Health (NIOSH), Bangi, Selangor (azlanabas@ukm.edu.my; jasmin.arifshah@upm.edu.my; nurshazwanie@gmail.com; deyana@ukm.edu.my; syttymazianbintimazlan@gmail.com) Doi: https://doi.org/10.22452/jati.vol25no2.5

\begin{abstract}
Since the beginning of the $21^{\text {st }}$ century, urban agriculture has been weighed as a strategy to address the loss of urban livability. This study will address three key aspects: 1) urban ecosystem services in Southeast Asia; 2) sustainable urban agriculture in Southeast Asia; and 3) enhancing urban ecosystem services through Southeast Asian urban agriculture. In the literature on environmental protection, the importance placed upon urban environments has been relatively limited as compared with other habitats such as wetlands or forests. Currently, urban agriculture is complementary to rural development (mainly by providing perishable goods such as fruits, meat, and eggs), and it is now well-established that it is developing community food supply networks. These and related issues call for a deeper understanding of the relationships between plants, city dwellers and the urban climate, which will help set the foundations for permanently upgradable structures capable of adjusting to a world that changes every day.
\end{abstract}

Keywords: agriculture, urban ecology, sustainable ecosystem, sustainable development, environmental management 


\section{Introduction}

Half of the world's population now resides in towns. Due to the concentration of population in urban areas, a vast majority of the world's population will reside in metropolitan regions by 2050. Unfortunately, two of the world's most pressing issues today are still found in cities: deprivation and environmental destruction. Poor air and water quality, inadequate water supply, waste management issues and rising energy use are aggravated by growing population density and urban demands (Pauleit \& Duhme, 2000). Urban planning is essential for managing these and other challenges as urban areas of the world swell. In general, urban areas are at the center of politics, economics, and culture. Materials, money and services are concentrated, and thus the population will be even more concentrated in such areas (Murata \& Kawai, 2018). Such concentrated populations in the urban areas cause urban ecosystem services to become degraded. The degradation of urban ecosystem services will lead to the loss of the urban livability, which eventually will cause imbalances in urban development (Rosehan, Abas, \& Aiyub, 2020).

Urban agriculture has been a topic discussion since the beginning of this century as one of the solutions to combat the degradation of urban livability (Abas, Aziz, Tahir, Othman, \& Payus, 2019). Wagstaff and Wortman (2013) have most concisely described urban agriculture as "all modes of agricultural development (food and non-food products) that exist inside or around cities." Government agencies and the peer-reviewed literature have reached an agreement on this loose interpretation of urban agriculture, which includes all animals or plants production in or near towns, whether for personal use or for sale, and whether soil or hydroponic (Rezai, Shamsudin, \& Mohamed, 2016). The ability of urban agriculture to meet a portion of global food demand shows some promise, as studies have shown that urban fruit and vegetable crop production can often be higher per square meter than in rural areas (Poulsen, McNab, Clayton, \& Neff, 2015). A number of authors have tried to estimate the percentage of total global supplies provided by urban farming, with one commonly reported figure claiming that it accounts for 15-20 percent of the world's total food supply (Bastiononi, Marchettini, Panzieri, \& Tiezzi, 2001). Other authors have regarded this figure as a significant overestimation (Blake, 1999).

Although urban agriculture takes place in all the world's cities, there are still concerns as to where and how to improve research and development operation for this specific method of farming. The immense and ongoing process of urbanisation in Asia, Africa and Latin America has led to questions about the introduction of new "urban" resources, feeding the growing urban population, 
and managing the continually-moving peripheries of developing countries' cities. The key issue raised by agronomists, agro-economists and agrosociologists is whether urban and peri-urban farming are genuinely connected to urban ecosystem services; and if so, what are their primary issues? Does that type of farming require specific research work? The literature on the topic is very comprehensive, both in the natural sciences and in the social sciences, with a vast range of scientific papers, research bulletins and project studies (Awang, Shah, \& Aiyub, 2008).

This paper is a conceptual paper based on a review of past literature on the topic of urban agriculture and ecosystem services. This paper contains the following assertions about the future of urban ecosystem services. The population pressure of cities in Southeast Asia will not reduce ecosystem services concurrently if governments are willing to allow urban dwellers and local authorities to explore urban agriculture. To address this hypothesis, this study will discuss three main aspects: 1) urban ecosystem services in Southeast Asia; 2) sustainable urban agriculture in Southeast Asia; and lastly 3) improving urban ecosystem services through urban agriculture in Southeast Asia.

\section{Urban Ecosystem Services in Southeast Asia}

\section{Urban Ecosystem}

\section{The Structure of Urban Ecosystem}

Urban ecosystems consist of biological components (plants, wildlife, and other aspects of life) and physical components (soil, water, weather, atmosphere, and topography). Such elements communicate within a defined environment across all environments. However, in the case of urban environments, the biological context often encompasses human beings, their demographic patterns and administrative frameworks, and the social and economic resources they use. The physical system involves structures, transit networks, changed materials (e.g. parking areas, roofs, and landscaping) and environmental changes arising from human decision-making. Physical aspects of urban environments include the use of resources and the production, storage, and export of products. Such energy and resource transition entails not only valuable goods (such as transport and housing) but also emissions, waste, and unnecessary power. City habitats are also colder than other environments that accompany them, with reduced rainwater absorption into the land, and with higher rates and quantities of surface runoff during rain and storms. Trace elements, calcium dust, particulate matter, and human-made chemical pollutants (e.g. fertilisers, chemicals, and 
toxins from medicinal and personal care products) are often distributed in towns (de Groot, Wilson, \& Boumans, 2002; Abas et al., 2019).

The development of broad metropolitan regions results in the reduction of woodland, lakes, deserts and other surrounding biomes into rural, agricultural, commercial and transport-related areas. Such conversion can contribute to the development of barren land. In addition, the cycle of turning residual remnants of natural or rural vegetation into ever-smaller patches and increasingly high amounts of sub-optimal habitat has been observed at the borders between the existing native habitats and those that have been changed for human use. These "edge ecosystems" hinder adapted types of plants and animals - that is, organisms that can withstand a limited set of environmental conditions. In addition, downwind and downstream non-urban habitats are exposed to elevated rates of water runoff, noise emissions, and invasive species introduced (Rosehan et al., 2020).

\section{Urban Ecosystems in Southeast Asia}

Urban ecosystems in Southeast Asia are essentially a tropical dry climate due to the region being so close to the equator. Southeast Asian cities make up 47 percent of the population, with regional urbanisation rates varying from 20 percent in Cambodia, to 53 percent in Indonesia and 100 percent in Singapore (Diehl, Sia, \& Chandra, 2018). With a broad urban population base of 294 million people, South East Asia is increasingly urbanised. Compared with Asia-Pacific's average annual growth of $2.7 \%$ in the 1990 s, Southeast Asia's urban population increased by $3.6 \%$ annually in the same timeframe. Although urban population development accelerated after 2000, the average annual increase over the last decade stayed below 2.6 per cent. Estimates suggest that Southeast Asia will reach $50 \%$ urbanisation by 2019 , with an additional 36 million people bringing its urban population to 330 million (Awang et al. 2008).

There are some unique characteristics of urbanisation in Southeast Asia, and two of them require national and sub-national political attention. First, cities in the area are undergoing a continuous cycle of development and transition. Between 1950 and 2014, the urban population in the area grew 11-fold from 26 million to 294 million. Since 1990, Southeast Asian cities have gained 154 million people - more than all the entire population of Brunei, Indonesia, Malaysia, Laos, and the Philippines. There is no historical or Western counterpart of such a major population change of metropolitan regions. The rate of urban population growth is projected to slow down over the coming decades, but policymakers will remain trying to identify creative ways to tackle this dynamic trend (Konijnendijk, Annerstedt, Busse Nielsen, \& Maruthaveeran, 2013). 
Second, despite the presence of many large cities, urbanisation in South East Asia is geographically extensive. In 2010,73\% of the urban population in the country lived in small cities (below 500000 inhabitants) and medium-sized cities (from 500000 to 1 million inhabitants) (Poulsen et al., 2015). This will not change significantly until 2030, when more than two-thirds of the urban population of the country will live in small and medium-sized cities $(61 \%$ and $5.5 \%$ respectively). Metropolitan areas (with between 1 million and 10 million inhabitants) are home to 22 per cent of Southeast Asia's metropolitan population, and their urban density is anticipated to slip slightly to 20 per cent by the end of the next decade (Barthel \& Isendahl, 2013).

\section{Urban Ecosystem Services}

In recent years, a growing body of literature has enhanced our understanding of urban ecosystem services across their biophysical, economic, and socio-cultural dimensions. In addition, major initiatives such as the Millennium Ecosystem Assessment and the Economics of Ecosystems and Biodiversity (TEEB, 2011) have highlighted urban ecosystem services and have also received significant attention as part of the policy discourse on green infrastructure. Yet, regardless of the fact that more than half of the world's population now lives in city areas, the attention paid to urban ecosystems in ecosystem services research has been relatively small compared to other ecosystems, such as wetlands and forests. The goal of this segment is to identify and explain ecosystem services offered in urban areas and how they can lead to improvements in the quality of life in cities.

Building on previous classifications of ecosystem services (Daily, 1997; de Groot et al., 2002), the Millennium Ecosystem Assessment (Ecosystems and human well-being, 2005) and the Economics of Ecosystem Services and Biodiversity (TEEB, 2010) grouped ecosystem services into four main categories: provisioning, regulation, habitat, and cultural and livability services. (TEEB, 2010) (Figure 1). Provisioning services includes all material products derived from ecosystems, including genetic resources, food and fiber, and fresh water. Regulation services include all the benefits derived from the regulation of ecosystem processes, such as the regulation of climate, water, and some human diseases. Cultural services are non-tangible benefits which people derive from ecosystems via spiritual development, cognitive development, reflection, recreation, and esthetic experience, as well as their capacity to support knowledge systems, social relations and esthetic values. Finally, support or habitat services include those required for the production of all other ecosystem services. Examples usually 
involve nutrient cycling, biomass production, species habitat provision, water cycling, and the maintenance of genetic pools and evolutionary processes.

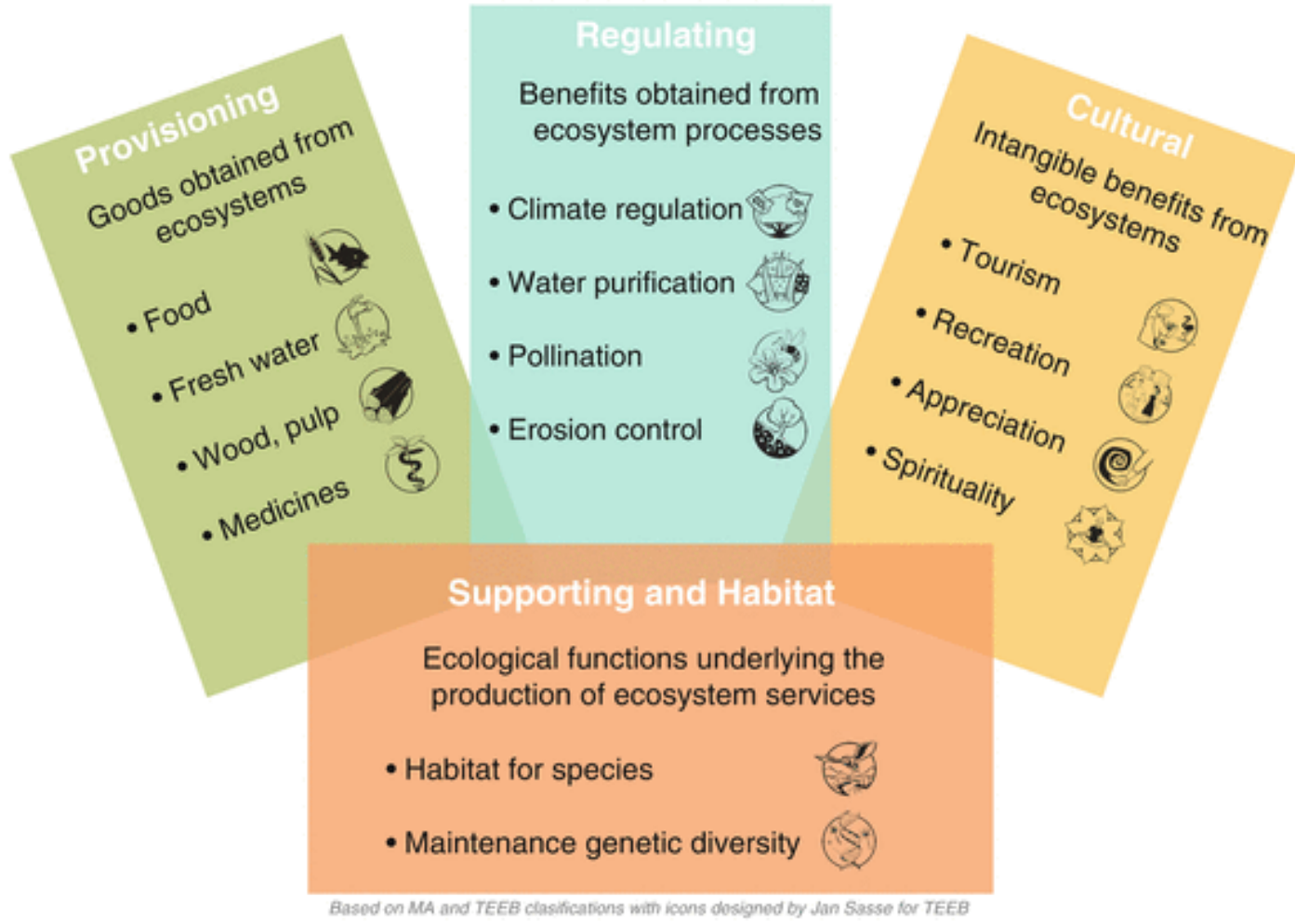

Figure 1: Classification of ecosystem services based on the Millennium Ecosystem Assessment (Ecosystems and human well-being, 2005) and the Economics of Ecosystems and Biodiversity initiative (Wittmer \& Gundimeda, 2012) (Produced by Gómez-Baggethun and Barton [2013] with icons designed by Jan Sasse for TEEB. Icons reproduced from Jan Sasse for TEEB. Published with kind permission of Jan Sasse and TEEB [2013].)

Because various environments have different forms of ecological resources, general classifications need to be tailored to particular types of ecosystems. Urban ecosystems are particularly important in providing services that have a direct impact on human health and safety, such as air purification, noise reduction, urban cooling, and runoff mitigation. However, the most relevant ecosystem services on a given scale vary greatly depending on the environmental and socio-economic characteristics of each geographical location. The following section, building on previous research on the topic, contains an 
overview of the main ecosystem resources offered in urban environments, utilising the Millennium Ecosystem Assessment and the TEEB project as key classification systems (Gómez-Baggethun \& Barton, 2013).

\section{Provisioning Services}

Food Supply

Urban food production occurs in peri-urban farms, on top of buildings, in back gardens and community gardens (Barthel, Folke, \& Colding, 2010). In many other geographical contexts, cities generate only a small proportion of the foods they eat, greatly depends on other areas to meet their needs (Ernstson et al., 2010). However, in some geographical regions and in particular times, food production from urban agriculture may play an important role in food security, particularly during political and economic crises (Barthel \& Isendahl 2013).

\section{Water Supply}

The expansion of cities across the world poses new problems in obtaining water to satisfy community needs (Fitzhugh \& Richter, 2004). Ecosystems provide communities with fresh water for and help guarantee that water flows are treated and regulated. The volume of usable water is influenced by the vegetation cover and forested areas in the city catchment area.

\section{Regulating Services}

\section{Urban Temperature Regulation}

Ecological technology in cities controls local temperatures and attenuates the impacts of coastal thermal islands (Moreno-Garcia, 1994). Water areas, for example, buffer extreme temperatures by absorbing heat in the summer and releasing it in the winter. Likewise, in the hottest months, vegetation reduces temperatures by shading and evapotranspiration by absorbing heat from the air, especially when humidity levels are low. Water from the plants collects heat as it evaporates, reducing the temperature in the process. Trees also help control local surface and air temperatures by absorbing solar radiation and shading areas, such as streets and pavements that would otherwise accumulate heat. Decreasing city heat loading is one of the most important regulations of ecosystem services provided to cities by trees (McPhearson, 2011). 
Noise Reduction

Traffic, construction, and other human activities make noise a significant pollution problem in cities which affects health through stress. Urban soils and plants can reduce noise pollution by absorbing, deviating, reflecting and refractive sound waves (Fang \& Ling, 2003). In rows of tree plantings, sound waves are reflected and refracted, dispersing vibrational wave through the branches and trees. It has been shown that different species of plants reduce noise differently (see, e.g., Pathak, Tripathi, \& Mishra [2007]).

\section{Air Purification}

Air pollution from transport, industry, domestic heating and urban solid waste incineration is a major concern for the quality of environmental and human health in the urban environment, and may lead to an increase in respiratory and cardiovascular diseases. Urban vegetation can improve air quality by removing pollutants from the atmosphere, including ozone (O3), sulfur dioxide (SO2), nitrogen dioxide (NO2), carbon monoxide (CO) and particulate matter less than $10 \mu \mathrm{m}$ (PM10) (Escobedo et al., 2008). Although there have been substantial variations in efficiency between plant types (e.g. between deciduous and evergreen plants), urban trees have been found to be highly critical for the purpose of intercepting air pollutants (Aylor, Garner, \& Johnson, 2003).

\section{Moderation of Climate Extremes}

Climate change is increasing the frequency and severity of environmental extremes. This presents a growing obstacle for communities, particularly those situated in coastal areas (Zahran, Brody, Vedlitz, Grover, \& Miller, 2008). In Europe, heat waves have been the most significant threat, causing human deaths over the last decade. For example, the 2003 European heat wave was responsible for more than 70,000 excess deaths. Ecological protection consisting of mangroves, deltas and coral reefs will serve as a natural shield that protects cities from significant climate disasters and threats, including earthquakes, heatwaves, flooding, hurricanes and tsunamis. This protection will significantly mitigate the harm done to coastal communities (Kerr \& Baird, 2007).

\section{Runoff Mitigation}

Increasing the porous land region of communities contributes to higher levels of surface water runoff, which then raises the susceptibility to river pollution. Vegetation decreases surface erosion after precipitation by intercepting water in 
leaves and stems. The underlying soil often decreases the rate of penetration by serving as a buffer and retaining water in pore spaces until it percolates as flowthrough. Urban landscapes with 50-90 per cent waterproof cover will lose 40-83 per cent of rainfall to surface runoff, relative to 13 per cent in forested landscapes (Bonan, 2002).

\section{Waste Treatment}

Ecosystems filters and decomposes organic waste from urban effluents by storing and reusing waste through dilution, integration and the re-composition of chemicals (TEEB, 2011). Wetlands and other marine structures, for example, remove sewage from human activities. This lowers nitrogen rates and the emissions of municipal wastewater. Plant populations in industrial soils may also play a significant role in the decomposition of other labile and recalcitrant litter forms. In urban waterways, nitrogen retention can be improved by the introduction of rough woody litter, the creation of in-channel gravel fields, and the expansion of vegetation buffer zones and tree cover (Booth, 2005).

\section{Pollination, Pest Regulation and Seed Dispersal}

Pollination, insect management and seed dispersal are essential mechanisms in the adaptive nature of urban environments and may play a vital role in their long-term survival. However, pollinators, insect managers and seed dispersers are at risk of habitat destruction and degradation due to humanisation and extension. In this context, allotment gardens (known as community gardens throughout North America, i.e. plots of land made usable for human, noncommercial gardening), private gardens and other urban green areas have been found to be significant source areas (Ahrné, Bengtsson, \& Elmqvist, 2009).

\section{Global Climate Regulation}

Since metropolitan centers contain many concrete surfaces and large rates of fossil fuel emissions, the effects of climate change in towns may be compounded. Greenhouse gas pollutants in towns contain carbon dioxide $\left(\mathrm{CO}_{2}\right)$, methane $\left(\mathrm{CH}_{4}\right)$, nitrous oxide $\left(\mathrm{NO}_{2}\right)$, chlorofluorocarbons (CFCs) and tropospheric ozone $\left(\mathrm{O}_{3}\right)$. City trees serve as $\mathrm{CO}_{2}$ sinks by processing waste carbon as biomass during photosynthesis. As the volume of $\mathrm{CO}_{2}$ deposited is equal to the productivity of plants, increasing the number of trees will theoretically slow down the deposition of ambient carbon in industrial areas. Tree-planting projects are also an enticing choice for climate change mitigation (McPherson \& Simpson 1999). 


\section{Cultural Services}

\section{Recreation}

Since urban landscapes can be overwhelming, urban landscape recreation is one of the most important environmental resources in cities. Parks, parks, reservoirs and waterways offer a range of leisure options to improve human safety and well-being. For instance, a park experience can reduce stress, enhance contemplativeness, rejuvenate urban dwellers, and provide a sense of comfort and tranquility (Konijnendijk et al., 2013).

\section{Aesthetic Benefits}

Urban ecosystems play an important role as providers of aesthetic and psychological benefits that enrich human life with meanings and emotions. Aesthetic benefits from urban green spaces have been associated with reduced stress and increased physical and mental health. It has been found that a view through a window looking out at green spaces could accelerate recovery from surgeries, and that proximity of an individual's home to green spaces was correlated with fewer stress-related health problems and higher general health perception. People often choose where to live in cities based in part on the characteristics of the natural landscapes (Tyrväinen \& Miettinen, 2000).

\section{Cognitive Development}

Exposure to nature and green space offers numerous incentives for cognitive growth; increasing the capacity for environmental stewardship; and improving awareness of ecological resources. For example, urban forests and amenity gardens are also used for environmental education purposes and promote cognitive linkages to seasons and ecological cycles in technical and urban ecosystems. In the same manner, industrial parks, community gardens, cemeteries and other green spaces have been established to preserve essential bodies of local ecological information and have the ability to address the reported lack of ecological awareness among poorer societies (Pilgrim, Cullen, Smith, \& Pretty, 2008).

\section{Place Values and Social Cohesion}

Place qualities apply to the affectionately marked associations in locations. Studies performed in Sweden, for example, have identified sense of place to be a significant predictor of environmental stewardship, with interviewees displaying deep emotional links to their plots and nearby garden areas. Attachment to green spaces in communities will also give way to many significant social gains, such 
as civic harmony, fostering of shared values and community engagement (Gotham \& Brumley, 2002).

\section{Supporting Services}

Habitat for Biodiversity

Urban structures can serve a pivotal role as a sanctuary for several types of insects, amphibians, bees and butterflies. Well-designed green roofs will provide shelter for biodiversity threatened by improvements in urban land use. In cold and rainy regions, urban golf courses can have the ability to contribute to preserving wetland biodiversity. Old hardwood deciduous trees in Stockholm City National Park, Sweden, are used as a valuable site for organisms with strong dispersal potential in the area. Species diversity may plateau at intermediate rates of urbanisation, where many native and non-native species flourish, but usually decline as urbanisation intensifies (Colding, Lundberg, Lundberg, \& Andersson, 2009).

\section{Sustainable Urban Agriculture}

\section{Urban Agriculture}

Agriculture has often been tied to a fictional rural world and much of the time, its associated practices have been limited to that sense. Due to that situation, it has long been considered necessary to focus on rural crop output to feed the urban population. Even so, for many cities in developing countries around the world, this has turned out to be inappropriate, mainly due to the scarcity of infrastructure (transport, roads, and markets) and the low incomes of the underprivileged (Awang et al. 2008). Over time, however, the rise in deprivation and high unemployment rates, along with the incentives that the region, on the other hand, may bring, such as food demand and accessibility to markets, have spurred the growth of several cropping and food systems in cities and nearby areas. This has specialised mainly in the processing of fresh vegetables, milk, eggs and chickens. The term urban agriculture includes both the production of plants and livestock for domestic consumption and the generation of income in towns. Commercial agriculture frequently involves other interrelated operations, such as the development and distribution of agricultural materials and the postharvest processing and selling of agricultural goods (Rosehan et al., 2020).

Urban agriculture is characterised as domestic development or land in urban or peri-urban areas. As such, it is quite challenging, in most situations, to classify informal behavior with correct data and patterns (FAO, 2010). Urban agriculture involves the planting of vegetables and fruit trees, as well as other advanced crops (e.g. medicinal and ornamental), wood production, small-scale 
animal husbandry (from traditional livestock, such as farm animals, to local organisms, such as guinea pigs), beekeeping, and aquaculture (combined fish and plant farming) (Ghosh, 2004). It is usually performed in near proximity to markets, due to strong demand for space, and exists in small areas. Sustainable planting utilises municipal water and recycles agricultural waste and plays a beneficial role in the management of natural resources for a sustainable environment (FAO, 2010). Such products are freshly marketed, without further processing, as the majority of farmers engaged in urban farming are distinguished by a low degree of organisation.

Urban agriculture currently complements rural development (mainly by supplying perishable goods such as tomatoes, milk and eggs) and it is now well known that it strengthens urban food supply networks (Tiraieyari \& Krauss, 2018). Proof of the growing position of urban agriculture is available in several cities: urban agriculture covers more than 21,000 hectares in Cagayan de Oro City, Philippines (Saksena et al., 2014). In Havana, Cuba, about 12 per cent of urban land is devoted to agriculture (De Guzman, 2017). More than 11,000 hectares are used for agricultural development in Jakarta, Indonesia (Chandra \& Diehl, 2019). Output tends to be highly diversified. For example, in the city of Harare, Zimbabwe, it involves, among other items, corn, potatoes, flowers and livestock development (Ghosh, 2004). Approximately 100,000 tons of fresh food is produced annually in Dar es Salaam, Tanzania (Tiraieyari \& Krauss, 2018), and $100 \%$ of milk and $90 \%$ of eggs consumed in Shanghai are raised within the city limits (Tsuchiya, Hara, \& Thaitakoo, 2015).

\section{Type of Urban Agriculture}

Backyard Gardens

Backyard garden are part of the growth of household food production, which is mostly shared between friends, family, and neighbours, as it usually leads to surplus harvesting. Food can also be stored. Backyard gardens are helpful to neighbourhoods because neighbours may share both their backyards and various planting techniques that contribute to higher yields (Ghosh, 2004).

\section{Tactical Gardens}

Tactical gardening involves making use of the limited space available for farming practice without having to incur high costs. For example, an urban dweller might easily create a keyhole garden to cover a room planned for parking on the street. Tactical garden brings property that may easily have went to waste into productive use, and can be undertaken for fun or to generate income (Tsuchiya et al., 2015). 


\section{Street Landscaping}

Street landscaping is the landscaping of streets with some purposes, such as community parks, which residents in the area prefer to do. Not only do they make the streets look beautiful; they also purify the air that creates a clean environment. Because they are mainly situated along highways, their added value is their potential to reduce urban stormwater runoff (Tsuchiya et al., 2015).

\section{Forest Gardening}

Forest gardening refers to the art of planting inside the urban forest. Forest planting is accomplished by growing various trees, vegetables and fruits cultivated in urban environments. Trees typically provide an atmosphere conducive to crop production, which is why they tend to ensure that trees remain safe and may render deforestation a non-factor in urban settings. Forest gardens may also be part of afforestation activities that promote tree planting as a step towards mitigating the effects of global warming in urban areas (Saksena et al., 2014).

\section{Greenhouses}

Greenhouses allow the cultivation of agriculture in rural, industrial and public urban areas. Greenhouses require a significant amount of land to be set up, based on the crops being grown. They provide the opportunity to grow a crop all year round, because they offer a regulated atmosphere in which the crops may be exposed to the conditions needed for their production (Ghosh, 2004).

\section{Rooftop Gardens}

Although urban areas have restricted land, this does not imply that agriculture cannot be practiced. This is where rooftop room falls in because it can be conveniently used for growing tomatoes, fruits and herbs. Another upside of rooftop gardens is that they will help minimise urban heat in the island as well as enhance air quality. Roof gardens may also be used to embellish leisure facilities (Chandra \& Diehl, 2019).

\section{Green Walls}

A green wall includes the development of plants or food crops in the exterior or inner area of a building. This does not require much space, because the process used helps to provide the food with enough water and uses soil on the walls. This is a safe approach to reduce stormwater pollution (Chandra \& Diehl, 2019). 


\section{Vertical Farms}

Vertical farms entail upward cultivation theoretically in order to increase the agricultural footprint. Green walls may be used as a vertical farm system, as they often require limited space and are placed on the sides of vertical walls (Chandra \& Diehl, 2019).

\section{Animal Husbandry}

Animal husbandry is the method of rearing farm livestock in urban environments. An urban dweller may select a location appropriate for the care of various types of animals or to concentrate on particular animals, such as chickens, goats, rabbits or sheep. Some communities restrict the number and type of animals that can be housed (Ghosh, 2004).

\section{Urban Beekeeping}

Urban beekeeping is a probability, but it comes with a number of local authority constraints and laws based on the area and the region. In other words, the requirements for apiculture may vary from city to city. Nonetheless, they provide many advantages to the surrounding community. Bees are essential to the environment, not only generating honey but also serving as pollinators and promoting biodiversity (Chandra \& Diehl, 2019).

\section{Aquaponics}

Aquaponics refers to rearing marine animals such as shrimp in a metropolitan environment. This requires a device that collects stormwater from inside the area, which then produces a self-sustaining recirculation network in tanks or artificial fishponds. This is an economical way to grow crops and offers an additional source of protein (Saksena et al., 2014).

\section{Improving Urban Ecosystem Services through Urban Agriculture in Southeast Asia}

\section{Potential Benefits}

Social Development

Urban agriculture may connect in at least three (related) ways to social growth. First, urban agriculture can serve as an essential part of food protection strategies. In developed nations, communities use food-management measures to sustain their people and combat persistent poverty. Examples include the Pattaya-Chon Buri, Thailand, known as 'the area that ended poverty,' and Davao City, Philippines, which has incorporated urban agriculture into its food security 
planning policies (De Guzman, 2017). Throughout developing countries, communities are utilising urban agriculture to provide people with exposure to nutritious and fresh produce. Top countries include Singapore City and Hanoi, Vietnam, while Phnom Penh, Cambodia and Ho Chi Minh District, Vietnam may be seen as leaders in Southeast Asia (Saksena et al., 2014). In certain of these regions, urban agriculture is an effective resource for addressing 'food deserts', i.e. low-income communities lacking grocery stores or markets. In such places, residents have little to no exposure to safe and organic food, since supermarkets and other stores have been moved to cities, attracting more wealthy consumers (Diehl et al., 2018).

Secondly, urban agriculture may be used to grow the economy. This applies, in turn, to urban planting as an initiative to improve social unity amongst various communities in the community, to provide job and educational opportunities for migrant people and as a crime reduction method. Many examples may be given, such as the Intercultural Gardens in Bandung, Indonesia (Chandra \& Diehl, 2019), Rising Power Inc. as a Youth Training Centre; the Rehabilitation Park in Manila as a big development initiative for work growth (Tiraieyari \& Krauss, 2018); and the Refugee Empowerment Agriculture System in Kuala Lumpur, where urban farming is used as a tool to support former prisoners in contributing to society.

\section{Environmental Development}

Sustainable cultivation offers numerous environmental advantages, such as rising biodiversity and raising emissions. Cities can use urban cultivation to alleviate and respond to climate change (De Guzman, 2017). For starters, Kuala Lumpur supports green infrastructure and urban agriculture in its stormwater management policy, much like Singapore, where urban agriculture is often used to increase biodiversity and grow food to feed the local community (Diehl et al., 2018). Furthermore, sustainable agriculture should be considered for the 'greening' of towns. For example, the Pasona $\mathrm{O} 2$ office farm 'greens' the urban forest of Bangkok by adding some nature to the sterile downtown office atmosphere (Razak, Wahid, \& Latif, 2019). Modern high-tech urban agriculture is often used to build closed-loop energy networks between various forms of agriculture (e.g. fish farming and grain production) and between agriculture and other operations. Significant instances of these closed-loop structures on urban farms are The Manila Plant and Rising Power Inc. (Saksena et al., 2014). Similarly, energy conservation and resource production have been accomplished by connecting agriculture to the manufacturing sectors at the same location, which is one of the key goals of 'agro-parks' (Tsuchiya et al., 2015). 


\section{Economic Development}

Urban agriculture offers economic benefits to cities in a variety of ways. First, it is a modern method of producing profits. Various companies are already using urban agriculture for commercial purposes. Examples include Panasonic Factory Solutions Asia Pacific (Singapore), which designs and develops indoor agricultural solutions for the commercial market (Diehl et al., 2018). Urban agriculture is also essential for entrepreneurship and new business growth. For example, The Plant in Seremban, Malaysia, provides unique incubator spaces and facilities to support start-ups in the food processing industry (Awang et al. 2008). Second, urban agriculture is essential for creativity, science and knowledge creation. Many high-tech urban farms act as pilots for modern (indoor) vertical-growing innovations and closed-loop networks.

As a consequence, various urban farms have on-site R\&D laboratories such as the Science Barge in Bangkok, Thailand (Tsuchiya et al., 2015) and Sky Green (Bravo, 2017) or are related to research institutions such as Urban Farmers AG in Jakarta, Indonesia (Chandra \& Diehl, 2019). Third, urban agriculture can give the potential for leisure, tourism and marketing purposes. Many urban farms are open to the public and arrange trips, which could be linked to other tourism attractions. In addition, working on a farm is a trendy way to spend free time and escape stressful daily life, especially for workers with high incomes. This often applies to 'crop mobbing,' in which members pay to work on a plant. For example, various rooftop farms in Singapore City provide the opportunity to carry out agricultural work while enjoying a beautiful view of Ipoh, Perak, Malaysia (Wahab, Razak, Sahani, \& Khan, 2020).

\section{Limitations and Challenges}

Urban environment systems in Southeast Asia have been evolving and fluctuating rapidly over the year. Urban agriculture is among the best options for improving urban ecosystem services. According to Saksena et al. (2014), urban agriculture not only provides food, but also increases other ecosystem services for urban areas. However, there are a few drawbacks for the countries in Southeast Asia and challenges that must be addressed.

Urban agriculture faces extreme pressure from non-agricultural economic practices, ecosystems, transportation, and so on. There is intense rivalry for access to human capital, but also to inputs (water, fertilisers) and property. In addition, urban and peri-urban environments are often heavily polluted by industry, domestic activities such as residential and office heating and cooling, for instance, and transport. Around the same period, livestock is considered to pollute the atmosphere by chemicals and industrial and 
conventional fertilisers. The goal for urban agriculture is thus to show that it does not pollute the city's climate, but instead creates nutritious food goods despite the often-contaminated urban environment. One challenge for the agronomist is that the "land" in the peri-urban and industrial areas can range from one hectare for rice in Taiwan to one square meter for organic beds in buildings in Havana. Such "land" can be as small as pond for growing aquatic vegetables, as in Hanoi (Saksena et al., 2014). As Awang et al. (2008) has said in the case of rural areas, the field is progressively a part of the landscape that is situated in the region, the city in the case of urban and peri-urban agriculture, and is a source of considerable interests for the farmer, as well as for all the people residing in the countryside. The definition of sustainability as defined in rural areas (Tiraieyari \& Krauss, 2018) must therefore be used in all its social, economic and environmental aspects to suggest crop systems adapted to the urban setting.

The usage of solid waste in urban agriculture is growing in developing countries. Kitchen and paper waste are the main components of waste in these cities, accounting for $42 \%$ and 19\%, respectively, in Metro Manila (Bravo, 2017). The nutrient quality of these wastes is very low; for example, in Kuala Lumpur, organic wastes contain just $0.29 \%$ nitrogen and $0.16 \%$ phosphorus (Baharuddin \& Sukimi 2007).

Numerous initiatives have been carried out to promote the use of various wastes from urban facilities by developing neighbourhood and personal grower compost plants in cities utilisng common compost chambers, bins, heaps, trench composting and vermiculture systems. In composting urban solid waste, consideration must be given to the risks to people's well-being $\mathrm{f}$ both consumers and farmers managing compost. This involves the reproduction of pathogenic bacteria (Salmonella, Entamaeba coli, and B. cereus), zoonosis, disease vectors, and environmental emissions from heavy metals and stable organic compounds. Waste processing based on a house-to-house waste disposal method and a robust composting cycle for the right raw materials may reduce these threats (Chandra \& Diehl, 2019).

The land, water supplies and climate of the built world are contaminated. Analyses have indicated that urban soils are more polluted than soils in rural areas. In one study, organic pollutant (benzo(a)pyrene) content was more than 0.05 mg.kg-1 in all urban soils tested, compared with only $15 \%$ of rural soils sampled (Tsuchiya et al., 2015). Related findings have been made in the numerous PCB and PAH pollution tests (PCB: polychlorobiphenyls, PAH: polycyclic aromatic hydrocarbon). The heavy metal content of urban industrial soils is frequently beyond allowable levels. $\mathrm{Cu}, \mathrm{Zn}, \mathrm{Pb}, \mathrm{Ni}, \mathrm{Cd}, \mathrm{Co}, \mathrm{Mn}$ and $\mathrm{Cr}$ 
were identified in a survey of various cities in South East Asia. Major industries and runoff from highway sinks are the major sources of this contamination (Diehl et al., 2018). This form of pollution is often widely found in drainage water and water used for aquaculture in Asian cities. Air emissions are mostly attributed to shipping, household heating and agriculture. In Hanoi, the overall average air composition of $\mathrm{NO} 2, \mathrm{CO} 2$ and $\mathrm{NO} 3$ was $0.04-0.09$ mg.m-3 and CO 2$5 \mathrm{mg} . \mathrm{m}-3$. The concentrations of $\mathrm{SO} 2$ and $\mathrm{CO} 2$ in urban districts are higher than the limits allowed (Saksena et al., 2014).

\section{Conclusion}

This study concludes that urban agriculture does improve the ecosystem services of the urban area. Well planned and designed urban agriculture needs to be empowered to produce better ecosystem services and increase urban livability. In many cities in developed nations, urban horticulture contributes significantly to the food protection and well-being of urban dwellers. It is expected that this agricultural activity will gain recognition for its benefits and services in the near future as cities, especially in the developing world, are growing on an unprecedented scale due to increasing rural-urban migration.

The urbanised environment brings to the fore a category of actors that plays a larger role every day, including in developing economies. Local authorities are aware that consumers are also voters. Satisfying their food protection requirements is now becoming a government imperative. Human well-being by nutritional protection and diversified diet is now becoming an essential problem that mayors and city leaders should no longer neglect. Urban horticulture would no longer be powered by growth, but by consumption. The manner in which food and non-food horticultural items are produced, manufactured, sold and packaged, up to the consumer's plate, should be planned by customers and suitable technology and food processes will then be modified and implemented. This is where general knowledge of the benefits of horticulture in terms of food production, as well as its benefits for the physical, cultural and environmental elements of society, is required. Further work would also provide a deeper understanding of the partnership between plants, urban dwellers and the environmental climate, and establish the foundation for sustainable, upgradable structures capable of adjusting to the day-to-day evolving environment. 


\section{Acknowledgments}

This study was supported by Universiti Kebangsaan Malaysia through a research grant (grant number: GUP-2018-032).

\section{References}

Abas, A., Aziz, A., Tahir, Z., Othman, A., \& Payus, C. (2019). Understanding ecosystem services: A shift in modern environmentalism. International Journal of Advanced and Applied Sciences, 6(12), 18-26. doi:10.21833/ijaas.2019.12.003

Ahrné, K., Bengtsson, J., \& Elmqvist, T. (2009). Bumble bees (Bombus spp.) along a gradient of increasing urbanization. PLOS ONE, 4(5). Retrieved 9 November 2019, from https://journals.plos.org/plosone/article?id=10.1371/journal.pone.0005574 Awang, A., Shah, A., \& Aiyub, K. (2008). Reassessing the meaning of quality of life and its application in environmental management discipline in Malaysia. Akademika, 72(1), 45-68.

Aylor, D., Garner, J. H., \& Johnson, D. (2003). Ecological effects of particulate matter. Environment International, 29(2-3), 213-239.

Baharuddin, S., \& Sukimi, M. (2007). City as a reflection of national identities: Early comparison between Jakarta and Kuala Lumpur. Akademika, 70(1), 319.

Barthel, S., \& Isendahl, C. (2013). Urban gardens, agriculture, and water management: Sources of resilience for long-term food security in cities. Ecological Economics, 86, 224-234.

Barthel, S., Folke, C., \& Colding, J. (2010). Social-ecological memory in urban gardens: Retaining the capacity for management of ecosystem services. Global Environmental Change, 20(2), 255-265.

Bastiononi, S., Marchettini, N., Panzieri, M., \& Tiezzi, E. (2001). Sustainability assessment of a farm in the Chianti area (Italy). Journal of Cleaner Production, 9(4),365-373

Blake, J. (1999). Overcoming the 'value-action 'gap' in environmental policy: Tensions between national policy and local experience. Local Environment, 4(3), 257-278

Bonan, G. B. (2002). Ecological climatology: Concepts and applications. Cambridge: Cambridge University Press. 
Booth, D. B. (2005). Challenges and prospects for restoring urban streams: A perspective from the Pacific Northwest of North America. Journal of the North American Benthological Society, 24(3), 724-737.

Bravo, M. (2017). Urbanization in the Philippines and Its Influence on Agriculture. In M. Yokohari, A. Murakami, Y. Hara, \& K. Tsuchiya (Eds.), Sustainable landscape planning in selected urban regions (pp. 97-110). Tokyo: Springer Japan. https://doi.org/10.1007/978-4-431-56445-4_9

Chandra, A., \& Diehl, J. (2019). Urban agriculture, food security, and development policies in Jakarta: A case study of farming communities at Kalideres - Cengkareng district, West Jakarta. Land Use Policy, 89, 104211. https://doi.org/10.1016/j.landusepol.2019.104211

Colding, J., Lundberg, J., Lundberg, S., \& Andersson, E. (2009). Golf courses and wetland fauna. Ecological Applications, 19(6), 1481-1491.

Daily, G. (1997). Nature's services: Societal dependence on natural ecosystems. Washington, D.C.: Island Press.

de Groot, R. S., Wilson, M. A., \& Boumans, R. M. (2002). A typology for the classification, description and valuation of ecosystem functions, goods and services. Ecological Economics, 41(3), 393-408.

De Guzman, C. (2017). Urban Agriculture in the Philippines: Initiatives, practices, significance, and threats. In M. Yokohari, A. Murakami, Y. Hara, \& K. Tsuchiya (Eds.), Sustainable landscape planning in selected urban regions (pp. 187-197). Tokyo: Springer Japan. https://doi.org/10.1007/978-4-43156445-4_16

Diehl, J., Sia, C., \& Chandra, A. (2018). Cities linked through food transboundaries: The case of Singapore as an agri-pelago. In E. Gottero (Ed.), Agrourbanism: Tools for governance and planning of agrarian landscape (pp. 4560). Cham: Springer. https://doi.org/10.1007/978-3-319-95576-6_4

Ecosystems and human well-being: Synthesis. (2005). Washington, DC: Island Press.

Ernstson, H., van der Leeuw, S. E., Redman, C. L., Meffert, D. J., Davis, G., Alfsen, C., \& Elmqvist, T. (2010). Urban transitions: On urban resilience and human-dominated ecosystems. AMBIO, 39(8), 531-545.

Escobedo, F. J., Wagner, J. E., Nowak, D. J., De la Maza, C. L., Rodriguez, M., Crane, D. E. (2008). Analyzing the cost effectiveness of Santiago, Chile's policy of using urban forests to improve air quality. Journal of Environmental Management, 86(1), 148-157.

FAO. (2010). Growing greener cities. Food and Agriculture Organization (FAO)'s website. Retrieved 9 November 2019, from http://www.fao.org/ag/agp/greenercities/en/resources/index.html 
Fang, C.-F., \& Ling, D.-L. (2003). Investigation of the noise reduction provided by tree belts. Landscape and Urban Planning, 63(4), 187-195.

Fitzhugh, T. W., \& Richter, B. D. (2004). Quenching urban thirst: Growing cities and their impacts on freshwater ecosystems. Bioscience, 54, 741-754.

Ghosh, S. (2004) Food production in cities. In R. Junge-Berberovic, J.-B. Baechtiger, \& W. J. Simpson (Eds.), ISHS Acta Horticulturae 643: International Conference on Urban Horticulture (pp. 233-239). Waedenswil, Switzerland: Acta Horticulturae.

Gómez-Baggethun, E., \& Barton, D. N. (2013). Classifying and valuing ecosystem services for urban planning. Ecological Economics, 86, 235-245.

Gotham, K., \& Brumley, K. (2002). Using space: Agency and identity in a publichousing development. City and Community, 1, 267-289.

Kerr, A. M., \& Baird, A. H. (2007). Natural barriers to natural disasters. BioScience, 57(2), 102-103.

Konijnendijk, C. C., Annerstedt, M., Busse Nielsen, A., \& Maruthaveeran, S. (2013). Benefits of urban parks: A systematic review. Copenhagen: International Federation of Parks and Recreation Administration (IFPRA).

McPhearson, T. (2011). Toward a sustainable New York City: Greening through urban forest restoration. In E. Slavin (Ed.), Sustainability in America's cities: Creating the green metropolis (pp. 181-204). Washington, DC: Island Press.

Moreno-Garcia, M. C. (1994). Intensity and form of the urban heat island in Barcelona. International Journal of Climatology, 14(6), 705-710.

Murata, T., \& Kawai, N. (2018). Degradation of the urban ecosystem function due to soil sealing: Involvement in the heat island phenomenon and hydrologic cycle in the Tokyo metropolitan area. Soil Science and Plant Nutrition, 64(2), 145-155. doi: 10.1080/00380768.2018.1439342

Pathak, V., Tripathi, B. D., \& Mishra, V. K. (2007). Dynamics of traffic noise in a tropical city Varanasi and its abatement through vegetation. Environmental Monitoring and Assessment, 146(1-3), 67-75.

Pauleit, S., \& Duhme, F. (2000). Assessing the environmental performance of land cover types for urban planning. Landscape and Urban Planning, 52(1), 1-20. https://doi.org/10.1016/s0169-2046(00)00109-2

Pilgrim, S. E., Cullen, L. C., Smith, D. J., \& Pretty, J. (2008). Ecological knowledge is lost in wealthier communities and countries. Environmental Science and Technology, 42(4), 1004-1009.

Poulsen, M. N., McNab, P. R, Clayton, M. L., \& Neff, R. A. (2015). A systematic review of urban agriculture and food security impacts in low-income countries. Food Policy, 55,131-146. 
Razak, H., Wahid, N., \& Latif, M. (2019). Anionic surfactants and traffic related emission from an urban area of Perak, Malaysia. Archives of Environmental Contamination and Toxicology, 77(4), 587-593. https://doi.org/10.1007/s00244-019-00656-3

Rezai, G., Shamsudin, M., \& Mohamed, Z. (2016). Urban agriculture: A way forward to food and nutrition security in Malaysia. Procedia-Social and Behavioral Sciences, 216, 39-45. https://doi.org/10.1016/j.sbspro.2015.12.006

Rosehan, N., Abas, A., \& Aiyub, K. (2020). Studies on the cultural ecosystem services in Malacca City. Planning Malaysia, 18(12), 133-144. https://doi.org/10.21837/pm.v18i12.749

Saksena, S., Fox, J., Spencer, J., Castrence, M., DiGregorio, M., Epprecht, M., Sultanab, N., Finucanea, M., Nguyend, L., \& Vien, T. D. (2014). Classifying and mapping the urban transition in Vietnam. Applied Geography, 50, 80-89. https://doi.org/10.1016/j.apgeog.2014.02.010

TEEB. (2010). The economics of ecosystems and biodiversity. London: Earthscan.

TEEB. (2011). TEEB manual for cities: Ecosystem services in urban management. Retrieved 9 November 2019, from http://www.teebweb.org/wpcontent/uploads/Study\%20and\%20Reports/Additional\%20Reports/Manua 1\%20for\%20Cities/TEEB\%20Manual\%20for\%20Cities_English.pdf

Tiraieyari, N., \& Krauss, S. (2018). Predicting youth participation in urban agriculture in Malaysia: Insights from the theory of planned behavior and the functional approach to volunteer motivation. Agriculture and Human Values, 35(3), 637-650. https://doi.org/10.1007/s10460-018-9854-8

Tsuchiya, K., Hara, Y., \& Thaitakoo, D. (2015). Linking food and land systems for sustainable peri-urban agriculture in Bangkok Metropolitan Region. Landscape and Urban Planning, 143, 192-204. https://doi.org/10.1016/j.landurbplan.2015.07.008

Tyrväinen, L., \& Miettinen, A. (2000). Property prices and urban forest amenities. Journal of Environmental Economics and Management, 39(2), 205-223.

Wagstaff, R., \& Wortman, S. (2013). Crop physiological response across the Chicago metropolitan region: Developing recommendations for urban and peri-urban farmers in the North Central US. Renewable Agriculture and Food Systems, 30(1), 8-14. https://doi.org/10.1017/s174217051300046x

Wahab, M., Razak, W., Sahani, M., \& Khan, M. (2020). Characteristics and health effect of heavy metals on non-exhaust road dusts in Kuala Lumpur. Science of the Total Environment, 703, 135535. https://doi.org/10.1016/j.scitotenv.2019.135535

Wittmer, H., \& Gundimeda, H. (Eds.). (2012). The economics of ecosystems and biodiversity in local and regional policy and management. London: Routledge. 
Zahran, S., Brody, S. D., Vedlitz, A., Grover, H., \& Miller, C. (2008). Vulnerability and capacity: Explaining local commitment to climate-change policy. Environment and Planning C: Government and Policy, 26(3), 544-562. 